\author{
Jakub Kufel \\ Uniwersytet Mikołaja Kopernika w Toruniu \\ ORCID: 0000-0003-1679-7213
}

\title{
Bezpieczeństwo państwa i niepokoje społeczne na łamach „Gazety Wyborczej" i „Tygodnika Solidarność" po wyborach 4 czerwca 1989 roku
}

\begin{abstract}
Streszczenie
Porozumienie Okrągłego Stołu otworzyło „okno ku wolności” i umożliwiło przeprowadzenie u Polsce kontraktowych uyborów, które odbyły się 4 i 18 czerwca 1989 roku. Kandydaci Komitetu Obywatelskiego „Solidarność” zdobyli niemal uszystkie (za wyjątkiem 1) mandaty, o które mogli starać się w uyborach do Sejmu i Senatu. Tak ogromne zuycięstuo było zaskoczeniem zarówno dla władz, jak i działaczy „Solidarności”. Rodziło jednak obauy o bezpieczeństwo państua zuiązane z obecnością wojsk Zuiązku Radzieckiego na terytorium naszego kraju, bezpieczeństwo społeczne związane z sytuacją gospodarczą oraz dotrzymanie przez władze okrągłostołowego kontraktu. Miały one odzwierciedlenie w debatach toczonych na łamach oficjalnej prasy solidarnościowej, tj. „Gazeta Wyborcza” i „Tygodnik Solidarność”. W tym artykule zastosowano metodę analizy prasy oraz analizę porównauczą u celu odpowiedzi na pytanie o diagnozy zagrożeń bezpieczeństua państua oraz propozycje ich przeciudziałania. Umożliwiło to uyciągnięcie uniosku, że debaty toczone na łamach oficjalnej prasy „Solidarnościowej” miały istotny upływ na podejmowane decyzje w okresie transformacji systemowej w Polsce.
\end{abstract}

Słowa kluczoue: bezpieczeństwo państwa, niepokoje społeczne, uybory kontraktoue, 4 czeruca 1989 roku, transformacja systemowa.

\section{National security and social unrest as presented in "Gazeta Wyborcza" and "Tygodnik Solidarność" after elections of 4 June 1989}

\begin{abstract}
The agreements of the Round Table opened the path to freedom and allowed to have a partially free parliamentary election which took place at 4 and 18 June 1989. The candidates of the Civic Committee of the "Solidarity" received all but one seats which they could fight for in this Parliamentary election. Both the authorities and the activists of the "Solidarity" were surprised by such an impressive victory. However, it aroused fears of national security due to the presence of the Soviet army at the territory of our country, of public security due to the economic situation and of honouring the agreements of the Round Table by the authorities. These fears were reflected in the discussions held in "Gazeta Wyborcza" and "Tygodnik Solidarność" (the official press
\end{abstract}


of the "Solidarity" movement). This article applies an analysis of the press and a comparative analysis in order to answer the question about the diagnosis of a threat to national security and proposed counteractions. It allowed to draw the conclusion that the discussions held in official "Solidarity" newspapers had a significant influence on the decision making in the transformation period in Poland.

Keywords: national security, social unrest, parliamentary elections of June 1989, 4 June 1989, system transformation.

\section{Wprowadzenie}

Porozumienie Okrągłego Stołu było pieruszym krokiem do zmian w Polsce. Uchylone „okno do wolności” umożliwiło organizację kontraktowych wyborów do Parlamentu. Brawurowa kampania przeprowadzona przez Komitet Obywatelski „Solidarność” przyniosła pozytywny skutek w postaci zuycięstwa w wyborach, które odbyły się w czerucu 1989 roku, a w konsekwencji utworzenie pieruszego niekomunistycznego rządu pod przewodnictwem Tadeusza Mazowieckiego. Tak znaczące zuycięstwo strony solidarnościouej zaskoczyło nie tylko działaczy „Solidarności” i przedstawicieli władz, ale było także niespodziewane dla społeczeństwa żyjącego przez kilkadziesiąt lat w niesuwerennym państwie, w którym działania władz były podporządkowane interesom Związku Radzieckiego.

Okres od uyborów 4 czeruca do powołania rządu Tadeusza Mazowieckiego charakteryzowały niepokoje społeczne związane między innymi z obecnością wojsk Związku Radzieckiego na terenie Polski, trudną sytuacją gospodarczą naszego kraju czy obawą o niedotrzymanie przez władze okrągłostołowego kontraktu ${ }^{1}$. Zagadnienia związane z zagrożeniami bezpieczeństua państua oraz niepokojami społecznymi stanowiły

\footnotetext{
1 Zob. J. Skórzyński, Rewolucja Okragłego Stołu, Społeczny Instytut Wydawniczy Znak, Kraków 2009; A. Dudek, Reglamentowana rewolucja. Rozkład dyktatury komunistycznej $w$ Polsce 1988-1990, Arcana, Kraków 2005; K. Trembicka, Okrąty stót w Polsce: studium o porozumieniu politycznym, Wydawnictwo Uniwersytetu Marii Curie-Skłodouskiej, Lublin 2003; Okragty Stót. Dokumenty i materiaty, Zapol, red. W. Borodziej, A. Garlicki, Szczecin 2004; P. Codogni, Okragty Stót, czyli polski Rubikon, Prószyński i S-ka, Warszawa 2009; Okragły Stót. Dwadzieścia lat później, red. W. Polak (i in.), Wydawnictwo Adam Marszałek, Toruń 2009; P. Kowal, Koniec systemu władzy. Polityka ekipy gen. Wojciecha Jaruzelskiego w latach 1986-1989, Trio, Warszawa 2012.
} 
istotny temat na łamach oficjalnej prasy solidarnościowej - „Gazety Wyborczej”2 i „Tygodnika Solidarność”3.

Celem artykułu jest przybliżenie stanowisk ukazujących diagnozę zagrożeń bezpieczeństua państua oraz propozycje ich przeciudziałania. Przeanalizowano i porównano artykuły zawarte w „Gazecie Wyborczej” oraz „Tygodniku Solidarność”, aby odpowiedzieć na pytanie o upływ tych pism na podejmowane decyzje w okresie transformacji systemowej w Polsce. Zakres chronologiczny pracy obejmuje okres od 4 czerwca - I tury zuycięskich dla KO „Solidarność” wyborów czerucouych do 24 sierpnia - exposé Tadeusza Mazowieckiego, które rozpoczęło proces transformacji systemowej w Polsce i zmieniło paradygmat myślenia o bezpieczeństwie państwa. W artykule przyjęto układ chronologiczny, który w lepszym stopniu odzwierciedla specyfikę prowadzonych debat na łamach oficjalnej prasy solidarnościowej. W artykule zastosowano metodę analizy prasy oraz analizę porównawczą w celu odpowiedzi na pytanie o diagnozy zagrożeń bezpieczeństua państua oraz propozycje ich przeciudziałania.

\section{Radość... i chwila namysłu}

Zuycięstwo w I turze uyborów kandydatów KO „Solidarność” wywołało ogromny entuzjazm, ale także obawy społeczne o dotrzymanie przez władze porozumienia podpisanego przy Okrągłym Stole. 6 czerwca 2019 roku Adam Michnik opublikował na łamach „Gazety Wyborczej” artykuł pt. Radość... i chwila namystu. Zurócił w nim uwagę na przełomowy charakter zuycięstua, które miało wóuczas miejsce, uskazując, że 4 czerwca był „POLSKIM ŚWIĘTEM”. Jednocześnie podkreślił, że tak masoue poparcie społeczne stanowi konkretne zobowiązanie na przyszłość. Ostrzegał przed retoryką „tryumfalistyczno-konfrontacyjną”, uskazując na potrzebę budowania dialogu i kompromisu z władzą. Było to szczególnie istotne z punktu widzenia bezpieczeństua społeczeństwa, które domagało się stabilizacji. Zurócił przy tym uwagę na wydarzenia

\footnotetext{
2 „Gazeta Wyborcza” - ogólnopolski dziennik opinii, który poustał w wyniku ustaleń przy Okrągłym Stole. Przed uyborami czerwcowymi stanowiła organ prasowy Komitetu Obywatelskiego „Solidarność". Pieruszy numer ukazał się 8 maja 1989 w nakładzie 150 tysięcy egzemplarzy. W „Gazecie Wyborczej” informowano, w jaki sposób oddawać ważne głosy, zachęcano do udziału u głosowaniu oraz promowano kandydatów KO „Solidarność”. Po wyborach stała się pieruszym opiniotwórczym niezależnym dziennikiem. Wydawana przez spółkę Agora. Jej redaktorem naczelnym był Adam Michnik. Zob. J. Kufel, Kampania wyborcza kandydatów KO Solidarność na łamach „Gazety Wyborczej” przed wyborami czerwca 1989 r. w Polsce [w:] Dwa dwudziestolecia. Geopolityka, państwo, społeczeństwo, red. P. Hauser, W. Mazurczak, Wydawnictuo Poznańskie, Poznań 2010.

3 „Tygodnik Solidarność” - tygodnik społeczno-polityczny ukazujący się od 3 kwietnia 1981 roku (pierwszy numer u nakładzie 500 tysięcy egzemplarzy). Poustał jako wynik realizacji porozumień sierpniowych. Jego wydawcą była Krajowa Komisja Porozumiewawcza NSZZ „Solidarność”, a redaktorem naczelnym Tadeusz Mazowiecki. Wydawanie pisma zawieszono w stanie wojennym i reaktywowano dopiero w czerwcu 1989 roku. Z funkcji redaktora naczelnego Tadeusz Mazowiecki ustąpił po powołaniu go przez Sejm na stanowisko Premiera. Od czeruca do urześnia 1989 roku uydano 18 numerów „Tygodnika Solidarność”.
} 
w Pekinie i Tibilisi, przestrzegając przed konsekwencjami nieprzestrzegania okrągłostołowych ustaleń. Zdaniem redaktora naczelnego „Gazety Wyborczej” 4 czeruca był istotnym, ale dopiero pierwszym krokiem w procesie ewolucji systemu4.

Pisząc te słowa, Adam Michnik nie znał jeszcze ostatecznych wyników wyborów. Okazało się, że strona solidarnościowa zdobyła w I turze 160 ze 161 mandatów poselskich, o które mogli się ubiegać w 460-osobowym Sejmie oraz 92 ze 100 mandatów senatorskich. Pytanie, jak zachowają się w tej sytuacji uładze na Kremlu, było otwarte. Dawid Warszawski zuracał uwagę na to, że dotychczas idea porozumienia z Moskwą „ponad głowami komunistów” była moralnie duruznaczna. Zuycięstwo otwierało drogę do takiego rozuiązania. Decyzje nie powinny być jednak podszyte lękiem wynikającym z braku wiedzy na temat sytuacji wewnętrznej w ZSRR, gdzie siły demokratyczne znalazły szerokie uznanie i weszły do struktur władzy 5 .

Adam Michnik z kolei podkreślił, że w stosunku do ZSRR dominują postawy skrajne. Z jednej strony Michaił Gorbaczow jest przedstawiany jako idealista uracający do pierwotnych założeń komunizmu, z drugiej jako przywódcę nieróżniącego się od Stalina. Zdaniem redaktora „Gazety Wyborczej” w ZSRR postępuje „destalinizacja, odrodzenie kultur narodowych i ducha wolności obywatelskich, eksplozja intelektualna i poustawanie niezależnych instytucji społecznych". Według niego skutki tych zmian dla Polski były jednoznacznie pozytywne, a retoryka antyradziecka oraz demonstracje pod hasłami "Sowieci do domu” przekreślały możliwość nawiązania poprawnych stosunków polsko-radzieckich, które stanowiły klucz z punktu widzenia polskiej polityki bezpieczeństua ${ }^{6}$. Zdaniem Stefana Bratkouskiego konflikt z ZSRR nie leżał w interesie żadnej ze stron. Reformy przeprowadzone u Polsce (szczególnie gospodarcze) mogły sprzyjać zmianom w Związku Radzieckim?

Wybory 4 czerwca w Polsce zakończyły się sukcesem. W zupełnie innej sytuacji znaleźli się Chińczycy. Gdy na Placu Tienanmen doszło do masouych protestów, zakończyły się one masakrą dokonaną przez wojsko. Miało to także szeroki oddźwięk w Polsce. Na łamach prasy solidarnościowej Wojciech Giełżyński postawił pytanie, czy starcie z protestującymi doprowadzi do cofnięcia polityki reform gospodarczych i politycznych? Jego zdaniem zmiany, które dokonały się u tym państwie, były nieodwracalne. Idea „tuancie”, czyli „Solidarności”, według publicysty miała upłynąć na rozszerzenie się protestu' ${ }^{8}$. Chińskie realia okazały się jednak odmienne od europejskich. Do dziś przykład Chin jest uskazywany jako alternatywa dla pokojouej transformacji w Europie. Na łamach „Gazety Wyborczej” szeroko informowano o sytuacji w Chinach. Zuracano uwagę na propagandę chińską, która dementowała doniesienia o ofiarach śmiertelnych, podkreślano, że rozpoczęło się w tym kraju „polowanie na czarounice”, informowano o wyrokach, jakie zapadały za udział w demonstracjach. Informacje były

\footnotetext{
${ }^{4}$ A. Michnik, Radość.. i chwila namystu, „Gazeta Wyborcza”, 6.06.1989, s. 1.

5 D. Warszauski, Poznać i dać się poznać, „Gazeta Wyborcza”, 8.06.1989, s. 3.

${ }^{6}$ A. Michnik, Polska - ZSRR. Patka i kompleks, „Gazeta Wyborcza”, 9.06.1989, s. 3.

7 S. Bratkouski, Bez nerwów, „Gazeta Wyborcza”, 13.06.1989, s. 2.

8 W. Giełżyński, „Tuancie” to po chińsku - solidarność, „Gazeta Wyborcza”, 10-12.06.1989, s. 7.
} 
przytaczane przez Gazetę głównie za pośrednictwem amerykańskich agencji prasouych. Tylko sporadycznie były one komentowane i odnoszone do sytuacji w Polsce.

„Tygodnik Solidarność” ze względu na to, że nie był dziennikiem, nie mógł tak szybko jak „Gazeta Wyborcza” reagować na wydarzenia w kraju i za granicą. Podobnie jak w przypadku „Gazety Wyborczej” zuycięstwo w I turze nie uwypukliło postaw tryumfalistycznych. Wręcz przeciunie - redakcja „Tygodnika” zachouywała dużą ustrzemięźliwość między innymi w obawie przed niedotrzymaniem przez uładze okrągłostołowego kontraktu?

\section{Uzupełnij drużynę Lecha...}

Przed II turą w Polsce, która miała odbyć się 18 czeruca, najważniejsze znaczenie miało uzupełnienie „drużyny Lecha” - wsparcie dla kandydatów, którzy nie otrzymali mandatu w II turze oraz poparcie dla tych przedstawicieli strony koalicyjno-rządowej, którzy mogliby ułatwić proces reform polityczno-gospodarczych.

Wśród kandydatów, którzy nie zostali uybrani w I turze, znalazł się Jan Józef Lipski - lider Komitetu Obrony Robotników, który przez wiele lat wspierał ich w walce o prawa człowieka. Startował w wyborach z Radomia, gdzie po czerucu 1976 roku wspierał ich w procesach politycznych, a po wybuchu stanu wojennego dołączył do protestu, jaki wybuchł w tym zakładzie pracy, co skończyło się dla niego aresztowaniem. Jego problemy z sercem, które były wynikiem ran odniesionych podczas II wojny światowej, miały wpływ na to, że władze wyraziły zgodę na jego wyjazd z kraju. Mimo tego wrócił, narażając się na aresztowanie, uspierał środowisko robotnicze, a w drugiej połowie lat 80. dążył do reaktyuacji Polskiej Partii Socjalistycznej ${ }^{10}$.

Okazało się, że słowo „socjalizm” zostało odrzucone przez radomskich protestujących, ponieważ wiązało się z poprzednim systemem. I choć Lipski znalazł się na uspólnym plakacie z Lechem Wałęsą ${ }^{11}$, to nie otrzymał uystarczającej liczby głosów, aby wejść do Senatu u I turze. Dostał 48,6\% głosów i zabrakło mu 5806 do granicy zuycięstua, mając ponad durukrotną przewagę nad Janem Pająkiem - zdobył 21,5\% głosów. Komitet Wyborczy udzielił znaczącego wsparcia „prezydentowi opozycji”, jak nazywano go nieformalnie u okresie PRL-u. Na łamach „Gazety Wyborczej” przypomniano jego rolę zarówno w opozycji przedsierpniouej, jak i znaczenia dla NSZZ „Solidarność”12.

Obawy o ostateczny wynik nie były jednak znaczne. Większy niepokój budziła kuestia uzupełnienia brakujących członków strony koalicyjno-rządowej tak, aby wynik uyborów nie był przez nich podważony. Władze przestrzegały przed „tryumfalizmem”,

\footnotetext{
9 Zob. „Tygodnik Solidarność”, 9.06.1989; nr 2(39), 16.06.1989, nr 3(40).

10 Zob. Ł. Garbal, Prezydent opozycji. Krótka biografia Jana Józefa Lipskiego, Warszawa 2017.

${ }_{11}$ Zob. A. Cherek, Plakaty wyborcze kandydatów Komitetu Obywatelskiego z Lechem Watęsa, „Krakouskie Studia Małopolskie” 2013, nr 18, s. 384.

12 Zob. H. Krall, Mały skrawek ziemi, „Gazeta Wyborcza”, 8.06.1989, s. 4.
} 
grożąc możliwością buntu aparatu partyjnego i resortu siłowego ${ }^{13}$. Mogło to skutkować odejściem od ustaleń Okrągłego Stołu, co obu stronom nie było na rękę. Aby dotrzymać kontraktu, zmieniono przed II turą ordynację wyborczą. Opozycja wyraziła zgodę na podział 33 mandatów z listy krajowej, na której znajdowali się odrzuceni przez uyborców kandydaci strony rządowej, na 33 okręgi wyborcze ${ }^{14}$. 12 czerwca Rada Państua przyjęła dekret, w myśl którego miało odbyć się ponowne głosowanie na miejsca z listy krajowej. Mogli brać w nich udział wyłącznie kandydaci koalicji. Ubiegać się o nie mogło dwóch nowych kandydatów zgłoszonych przez organy naczelnych władz organizacji, które zgłaszały listę krajową ${ }^{15}$.

Jacek Kuroń w wywiadzie udzielonym „Gazecie Wyborczej” zwrócił uwagę na to, że po I turze uyborów sytuacja po stronie władzy znacząco się skomplikowała. Porażka wyborcza oznaczała również dla Partii przegraną reformatorów. Po stronie władz pojawiły się więc głosy, że dialog z opozycją był błędem. Nie można więc jego zdaniem było trzymać się ustaleń u sprawie listy krajowej. Utrzymanie parytetu zgodnie z wynegocjowaną proporcją podziału mandatów 65/35\% miało być gwarantem utrzymania się przy władzy skrzydła proreformatorskiego i oddalić zagrożenie ze strony „betonu partyjnego”. Kuroń odniósł się też do zagrożenia interwencją radziecką, co przez wiele lat, jak podkreślał w tekstach publikowanych w drugim obiegu było granicą możliwych reform systemu politycznego: jest to uprawdzie czynnik decydujący, ale prawie od nas niezależny. Dopóki w Związku Radzieckim trwają przemiany, dopóty jesteśmy uzględnie bezpieczni, co znaczy, że możemy powoli i stopniowo iść ku niepodległości ${ }^{16}$.

Na łamach „Gazety Wyborczej” Adam Michnik odniósł się do propozycji wielkiej koalicji, która po wyborach miałaby przystąpić do zmiany sytuacji w kraju. Miała być ona oparta na współpracy strony rządowej i solidarnościowej. Redaktor naczelny wskazał na potrzebę uyciągnięcia lekcji z poustania na Węgrzech w 1956 roku i z nieudanych reform „polskiego października”. Jego zdaniem nie była ona wykluczona, o ile w Partii przewagę weźmie skrzydło reformatorskie. To ona dysponuje bowiem monopolem na aparat przemocy ${ }^{17}$. Uzupełnienie miejsc w Sejmie przez działaczy proreformatorskich miało być gwarantem pokojouych przemian i odsunąć groźbę

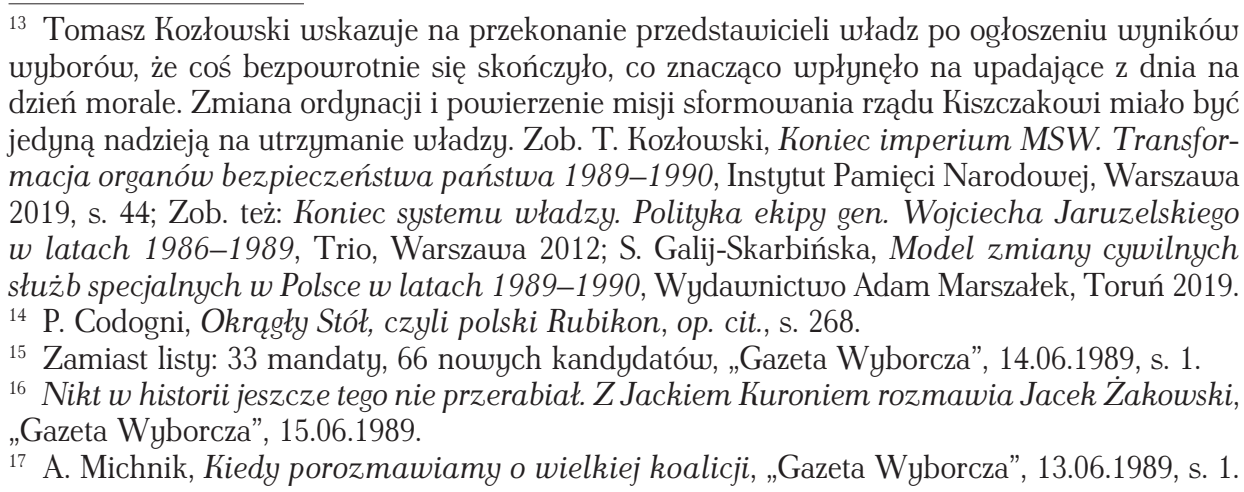


buntu ze strony przedstawicieli resortów siłowych. Przed II turą redaktor „Gazety Wyborczej" apelował do wyborców:

Głosować będziemy - to oczywiste - przede uszystkim na kandydatów »Solidarności«. Musimy ich uybrać, bowiem musimy być u Zgromadzeniu Narodowym tak silni, jak to tylko możliue. Ale głosować będziemy róunież po to, by uybrać sobie przeciuników i partnerów. Przeciuników, którzy będą respektowali reguły walki politycznej; partnerów, którzy okażą się zdolni do ewolucji, co pozwoli zbudować ład demokratyczny. Taka bowiem jest logika naszej sytuacji, że bez przemocy i krwi, bez wojny i rewolucji możemy zbudować instytucje demokratyczne i niepodległej Polski jedynie we współpracy z reformatorskim skrzydłem obozu władzy ${ }^{18}$.

W „Tygodniku Solidarność” Wojciech Wieczorek zwrócił uwagę na dość niską frekwencję wyborczą w I turze, która mogła być wynikiem niezadowolenia dużej części społeczeństua z kontraktu okrągłostołowego. Mogła być też wynikiem wykluczenia spowodowanego obniżającym się poziomem życia, uysokiej inflacji, upadającej gospodarki ${ }^{19}$. O ile 4 czerwca społeczeństwo mogło opowiedzieć się za zmianą, o tyle apatia była szczególnie widoczna 18 czerwca, kiedy do urn poszło niecałe 26\% upraunionych. Kandydaci strony koalicyjno-rządowej otrzymali 296 mandatów, uzupełniając skład Sejmu. W przypadku Senatu kandydaci Solidarności zdobyli 7 z 8 mandatów. Przepadł tylko Piotr Baumgart w rywalizacji z bezpartyjnym kandydatem Henrykiem Stokłosąa . Mimo niskiego udziału u głosowaniu nie było już wątpliwości, że uybory czerwcowe będą stanowiły moment przełomowy ${ }^{21}$. Pojawiło się natomiast pytanie, czy wejść do struktur władzy? Obauy przedstawicieli Komitetu Obywatelskiego dotyczyły przede wszystkim systemu sprawowania władzy. Bez głębokiej przebudowy struktury przedstauiciele „Solidarności” mogli być obarczeni uspółodpowiedzialnością za sytuację u państuie.

\section{Załamanie gospodarcze}

Po zuycięstwie w uyborach obawy posłów Komitetu Obywatelskiego dotyczyły u dużej mierze fatalnego stanu gospodarki polskiej. Dyskusja na temat refom gospodarczych miała uyprzedzić rozmowy o sformowaniu rządu. Wsparcie przywódców państw zachodnich miało istotne znaczenie z punktu widzenia rozpoczętych zmian. Bronisław Geremek zwrócił uwagę w uywiadzie udzielonym Eugeniuszowi Smolarowi, że chodzi nie o kolejne kredyty, a o pomoc dla reform, które umożliwią zmianę struktur rządzenia i gospodarowania ${ }^{22}$. Witold Trzeciakouski podkreślił, że projekt pomocy gospodarczej

\footnotetext{
${ }_{18}$ A. Michnik, Z kim usiadziemy, „Gazeta Wyborcza”, 16.06.1989, s. 1.

${ }^{19}$ W. Wieczorek, Krajobraz po wyborach, „Tygodnik Solidarność”, 16.06.1989, s. 1.

20 A. Dudek, Reglamentowana rewolucja..., op. cit., s. 329.

${ }^{21}$ Zob. K. Leski, Kropka nad i, „Gazeta Wyborcza”, 20.06.1989, s. 1.

${ }^{22}$ Najpierw reformy, potem rzad. Z Bronisławem Geremkiem rozmawia Eugeniusz Smolar z polskiej sekcji BBC, „Gazeta Wyborcza”, 23.06.1989, s. 1.
} 
przedstawiony prezydentowi Mitterandowi i premier Thatcher został przez MSW obwarowany warunkami, tj. stabilizacja gospodarki i walka z inflacją, co wymagało podjęcia decyzji gospodarczych mogących wywołać niepokoje społeczne związane ze zwolnieniami z pracy. Jego zdaniem nie było jednak odwrotu od pogłębionych reform $w$ kierunku wprowadzenia gospodarki rynkowej ${ }^{23}$.

Niepokoje zuiązane z sytuacją gospodarczą Polski były istotnym tematem na łamach „Gazety Wyborczej” po 4 czerwca 1989 roku. Miały one upływ na obniżenie poziomu bezpieczeństua społecznego państwa ${ }^{24}$. Jednym z punktów zapalnych była galopująca inflacja. Kartki na produkty żywnościowe nie miały swojego pokrycia ze uzględu na spadek cen żyuności ${ }^{25}$. Doprowadziło to do kryzysu u rolnictuie ${ }^{26}$. Odpowiedzią na te problemy miał być rządowy projekt likwidacji kartek oraz urynkowienia cen mięsa i wędlin ${ }^{27}$. Wobec tych zmian zaprotestowało Prezydium KKW, które na łamach „Gazety Wyborczej” zamieściło oświadczenie: „Wypowiadamy się przeciwko raptownym i skokouym poduyżkom cen ustalonych przez rząd. Decyzje dotyczące urynkowienia gospodarki powinny być podejmowane z całą rozuagą. NSZZ „Solidarność” stwierdza raz jeszcze, że polskiej gospodarce potrzebna jest głęboka reforma, której nie mogą zastąpić podwyżki cen. Każde inne działanie może doprowadzić do fali protestu"28. Masowe protesty wisiały na włosku.

O ile „Gazeta Wyborcza” miała być organem Komitetu Obywatelskiego, na łamach którego kandydaci „Solidarnościowi” prezentowali swój program, o tyle „Tygodnik Solidarność", który poustał w 1981 roku, wznowiony przed uyborami czerwcouymi i prowadzony przez redaktora naczelnego Tadeusza Mazowieckiego, miał być oficjalnym organem NSZZ „Solidarność” i uyrażać jego poglądy. To bardzo istotne z punktu widzenia przyszłych reform gospodarczych. 9 czerwca 1989 roku opublikowano na łamach pisma debatę dotyczącą tego, jaką rolę powinien pełnić NSZZ „Solidarność” - ma być związkiem roszczeniouym czy reformatorskim. Zdaniem Władysława Frasyniuka, który nigdy nie ukrywał swoich liberalnych poglądów, roszczeniowe związki przechodziły na całym świecie kryzys. W związku z rolą, jaką odgrywa „Solidarność” w procesie pokojouych przemian, musi uziąć na siebie odpouiedzialność za sytuację u państuie. Według Macieja Jankouskiego Solidarność powinna bronić przede wszystkim interesów ludzi wykluczonych, nadal poszkodowanych przez przedstawicieli nomenklatury, ale tym razem kapitalistyczną, która w związku z procesem uwłaszczenia korzystała z dobrodziejstu gospodarki rynkowej ${ }^{29}$.

${ }_{23}$ Plan Marshalla dla Polski. Wypowiedź profesora Witolda Trzeciakowskiego, eksperta „Solidarności” ds. gospodarki, „Gazeta Wyborcza”, 24-26.06.1989, s. 1.

${ }_{24}$ Zob. Obniżka poziomu życia. Oświadczenie Prezydium „Solidarności” w sprawie podwyżek cen, „Gazeta Wyborcza”, 28.06.1989, s. 1.

${ }^{25}$ K. Naszkouska, Mięso: za ile?, „Gazeta Wyborcza”, 28.06.1989, s. 1.

${ }^{26}$ L. Bojko, Chłopi czekali cała zimę, „Gazeta Wyborcza”, 30.06.1989, s. 1.

${ }^{27}$ A. Gzyło, W. Słowiński, Rządowy projekt urynkowienia. Jakie ceny?, „Gazeta Wyborcza”, 30.06.1989, s. 1.

${ }^{28}$ Lech Watęsa i kierownictwo „Solidarności”. Przeciw podwyżkom, „Gazeta Wyborcza”, 1-3.07.1989, s. 1.

${ }^{29}$ Czym jest, czym ma być NSZZ Solidarność, „Tygodnik Solidarność”, 9.06.1989, nr 2(39), s. 8. 
Debata toczona na łamach „Tygodnika Solidarność” nie przyniosła jednoznacznej odpowiedzi na pytanie o rolę zuiązku, bo przynieść jej nie mogła. „Solidarność” była nie tylko związkiem zawodouym, ale przede wszystkim ruchem społecznym, który miał zmienić sytuację u państwie, także gospodarczą. Zdawano sobie więc sprawę, że nie ma innej drogi niż rozwiązania rynkowe. Debata na temat zakresu i tempa reform będzie postępować uraz z rozwojem sytuacji w kraju. Warto zurócić uwagę na ostrożność $\mathrm{w}$ formułowaniu postulatów zmian gospodarczych zauważalną w „Tygodniku Solidarność” i usparcie polityki reform gospodarczych przez „Gazetę Wyborczą”.

\section{Wasz Prezydent. Nasz Premier}

Czwartego lipca 1989 roku Adam Michnik napisał przełomowy dla debaty publicznej na temat przyszłości Polski artykuł pt. Wasz Prezydent. Nasz Premier:

Potrzebny jest układ nowy, możliwy do zaakceptowania przez uszystkie siły polityczne. Nowy, ale gwarantujący kontynuację. Takim układem może być porozumienie, na mocy którego prezydentem zostanie wybrany kandydat z PZPR, a teka premiera i misja sformowania rządu powierzona kandydatowi „Solidarności”. Argumentował w nim, że w takim układzie to prezydent będzie gwarantem ciągłości władzy, umów międzynarodowych i wojskowych sojuszy, a rząd będzie miał mandat społeczny do dokonania stosounych zmian w państuie. Powinien opierać się na wielkiej koalicji, przez którą autor rozumiał wsparcie wszystkich sił demokratycznych u państwie ${ }^{30}$.

Zaproponowane przez Michnika rozwiązanie miało uspokoić osoby obawiające się reakcji Moskuy na zmiany w Polsce, a z drugiej stworzyć możliwość uspółpracy z siłami prodemokratycznymi także po stronie władz. Ta układanka polityczna wcale nie była taka prosta. Po pierusze, aby dotrzymać kontraktu zawartego przy Okrągłym Stole, gen. Jaruzelski musiał otrzymać większość głosów Zgromadzenia Narodowego. Mimo że "Solidarność” i Lech Wałęsa zachowali się powściągliwie nie uystawiając swojego kandydata na urząd prezydenta, poparcie dla Jaruzelskiego w obozie uładzy nie było tak oczywiste. Mimo nacisku ze strony PZPR, część posłów PSL i SD nie zamierzało go popierać, wyczuwając zapewne nastroje społeczne, których wyrazem były liczne manifestacje, szczególnie nastawionych radykalnie grup antykomunistycznych domagających się odejścia Jaruzelskiego. Podczas XIII Plenum KC PZPR generał stwierdził nawet, że nie zamierza kandydować, choć ostatecznie zmienił swoje zdanie w tej sprawie. Mogło być to efektem stanowiska Moskuy związanego z sytuacją w Polsce.

Parę dni po napisaniu artykułu Adam Michnik został przyjęty w Moskwie, co - jak tuierdzi Antoni Dudek - stanowiło zielone światło przejęcia części uładzy wykonawczej, ale nie oznaczało, że ZSRR nie będzie dążyć do zapewnienia sobie guarancji strategicznych interesów ${ }^{31}$. W artykule pt. Pożegnanie doktryny Breżniewa

30 A. Michnik, Wasz Prezydent. Nasz Premier, „Gazeta Wyborcza”, 4.07.1989, s. 1.

31 Zob. A. Dudek, Historia polityczna Polski 1989-2015, Społeczny Instytut Wydauniczy Znak, Kraków 2016, s. 53. 
Michnik jasno wyłożył swoje stanowisko dotyczące zagrożenia interwencją radziecką: „Staramy się myśleć, mówić i pisać o stosunkach polsko-radzieckich wolni od szantażu czołgami, z realistycznym wyczuciem interesów narodowych i państwowych wszystkich zainteresowanych. Staramy się wykarczować do końca stalinouskie dziedzictuo. Tak pojmujemy suoją pracę dla Polski demokratycznej i suwerennej" - argumentował ${ }^{32}$.

"Gazeta Wyborcza” dobrze wyczuwała niepokoje społeczne i trafnie diagnozowała zagrożenia bezpieczeństua. Odmienne stanowisko w sprawie uzięcia odpowiedzialności za rządy u Polsce przyjął Tadeusz Mazowiecki, który u „Tygodniku Solidarność” zamieścił swój polemiczny wobec Michnika artykuł pt. Spiesz się powoli. Zurócił w nim uwagę na to, że pogląd redaktora naczelnego „Gazety Wyborczej” wcale nie jest pouszechny, a tym bardziej w gronie członków OKP. Jego zdaniem Michnik stworzył świadomie fakt polityczny niedopuszczający innych rozwiązań. Tego typu rozwiązanie uyłącza jego zdaniem kierounictuo nad kluczouymi z punktu widzenia bezpieczeństua państua resortami, tj. MON, MSW, MSZ. Według Mazowieckiego artykuł Michnika nie odpowiadał też na pytania: co przemawia za trwałością koalicji z PZPR? Czy to dobry moment, aby ryzykować obarczeniem uspółodpowiedzialnością za sytuację w państuie, nie mając pełni kontroli? Czy jest po stronie „Solidarności” społecznie akceptowalny program wyjścia z kryzysu? ${ }^{33}$.

Pieruszym kandydatem na Premiera zaproponowanym przez Prezydenta Jaruzelskiego był Czesław Kiszczak. Okazało się, że nie miał on poparcia nawet wśród członków PZPR ${ }^{34}$. Z dużym dystansem odnosili się do niego także posłowie ZSL i SD, którzy dobrze wyczuwali nastroje społeczne. Chętniej poparli więc kandydata strony solidarnościowej. Lech Wałęsa miał już gotowe rozwiązanie, które tylko w teorii było alternatywą. Wśród potencjalnych kandydatów na premiera, tj. Jacek Kuroń - uznawany za radykała oraz Bronisław Geremek - mający zbyt silną władzę, nie byli akceptowalni przez stronę rządową. Jedynym dobrym kandydatem, który mógł być traktowany jako wyraz kompromisu, a tym samym akceptowalny był Tadeusz Mazowiecki, który został zaakceptowany i desygnowany na premiera przez Jaruzelskiego. „Nasz szef - naszym premierem. A więc zaskoczenie, radość i duma, ale także niepeuność i lęk” - czytamy w pieruszym komentarzu zamieszonym na łamach „Tygodnika Solidarność”35. Jan Dworak uskazał na dwa najważniejsze zagrożenia związane z powołaniem nowego rządu: ruch „Solidarność” nie był wystarczająco zinstytucjonalizowany, aby sprostać nowym wyzwaniom, a Komitet Obywatelski dopiero poszukiwał swojej tożsamości ${ }^{36}$.

Tadeusz Mazowiecki uystąpił w Sejmie 24 sierpnia 1989 roku podczas swojego słynnego exposé, mówiąc: „Przeszłość odkreślamy grubą linią. Odpowiadać będziemy jedynie za to, co uczyniliśmy, by uydobyć Polskę z obecnego stanu załamania”. W tym kontekście znamienny jest komentarz Adama Michnika:

\footnotetext{
32 A. Michnik, Pożegnanie doktryny Breżniewa, „Gazeta Wyborcza”, 5.07.1989, s. 1.

33 T. Mazowiecki, Spiesz się powoli, „Tygodnik Solidarność”, 14.07.1989, nr 7(44), s. 2.

34 Zob. K. Gottesman, Premier, „Tygodnik Solidarność”, 11.08.1989, nr 11(48), s. 23.

35 Red., Nasz szef - naszym premierem, „Tygodnik Solidarność”, 25.08.1989, nr 13(50), s. 1.

36 J. Duorak, Obliczalność, „Tygodnik Solidarność”, 25.08.1989, nr 13(50), s. 1.
} 
Możemy sobie uyobrazić linię przyszłego rządu jako wierną pluralizmowi i rozuadze. Takie właśnie stanowisko prezentował obecny premier, zasiadając w kierowniczych gremiach »Solidarności«. Czy są to jednak cechy wystarczające dla premiera rządu, funkcjonującego u tej rzeczywistości? Myślę, że premier tego rządu musi dysponować dynamizmem i zmysłem ryzyka. Musi mieć odwagę szybkiego podejmowania trudnych decyzji ${ }^{37}$.

Różnica zdań pomiędzy Michnikiem a Mazowieckim odzuierciedlała podział u samej „Solidarności”, który dotyczył tempa zmian u państwie u kontekście zagrożeń dla bezpieczeństua państua. Pieruszy niekomunistyczny rząd musiał zmierzyć się z nowymi wyzuaniami i niepokojami społecznymi oraz ze skutkami reform, które nie będą już obciążały komunistów, a przedstawicieli nowo uformowanego gabinetu.

\section{Podsumowanie}

Zuycięstwo w wyborach czerucowych otworzyło drogę do reform systemu politycznego. Zaskoczeni skalą zuycięstua działacze „Solidarności” nie mieli jednak jasno sprecyzowanej koncepcji działania. Czynnikiem limitującym zmiany w Polsce była obawa przed interwencją radziecką oraz zagrożenie związane z niedotrzymaniem przez władze porozumienia, które zawarto przy Okrągłym Stole. Mimo masouego poparcia dla „Solidarności” frekwencja uyborcza pokazała, że duża część społeczeństua jest apatyczna, niechętna procesowi zmian, a załamanie sytuacji gospodarczej prowadziło do licznych niepokojów społecznych. Przełamanie monopolu władz na informację umożliwiło prowadzenie debat i formułowanie stanowisk w tej sprawie na łamach oficjalnej prasy solidarnościowej. „Gazeta Wyborcza” była pieruszym opiniotwórczym dziennikiem kształtującym debatę publiczną i reagującym na bieżące wydarzenia w kraju i na świecie zuiązane między innymi z bezpieczeństuem państua. „Tygodnik Solidarność" stanowił oficjalny organ związku, zajmując stanowisko w istotnych kuestiach i diagnozując zagrożenia oraz proponując sposoby ich rozwiązania.

Analiza porównawcza tekstów prasowych pozwala na wyciągnięcie wniosku, że oba pisma nadawały ton debacie publicznej, dokonując diagnozy zagrożeń bezpieczeństua państua oraz propozycje ich przeciudziałania. „Gazeta Wyborcza” była otwarta na radykalne zmiany gospodarcze, konkretne działania reformujące system sprawowania władzy i postulaty wzięcia przez „Solidarność” odpowiedzialności za sytuację w państwie. „Tygodnik Solidarność” był znacznie ostrożniejszy w propozycjach zmian gospodarczych oraz politycznych. Debaty toczone na łamach oficjalnej prasy „Solidarnościowej” miały istotny upływ na podejmowane decyzje w okresie transformacji systemowej w Polsce. Ich ton był dyktowany przez redaktorów naczelnych pisma Adama Michnika i Tadeusza Mazowieckiego, których koncepcje można określić jako zestawienie poryuczości z ostrożnością. Mazowiecki, który po kilku tygodniach od opublikowania swojego polemicznego artykułu objął tekę premiera, musiał dokonać rewizji swojego stanowiska dotyczącego odpowiedzialności za sytuację w państwie.

37 A. Michnik, Moje życzenia dla nowego Premiera, „Gazeta Wyborcza”, 26-28.08.1989. 
Mimo tego hasło „spiesz się powoli” będzie dobrze charakteryzować styl sprawowania przez niego rządów. Michnik jeszcze przez wiele lat za pomocą „Gazety Wyborczej” kształtował poglądy opinii publicznej w duchu wsparcia reform politycznych.

\section{Bibliografia}

\section{Opracouania}

Cherek A., Plakaty wyborcze kandydatów Komitetu Obywatelskiego z Lechem Wałęsa, „Krakouskie Studia Małopolskie” 2013, nr 18.

Codogni P., Okrągty Stót, czyli polski Rubikon, Prószyński i S-ka, Warszawa 2009.

Dudek A., Historia polityczna Polski 1989-2015, Społeczny Instytut Wydawniczy Znak, Kraków 2016.

Dudek A., Reglamentowana rewolucja. Rozkład dyktatury komunistycznej $w$ Polsce 1988-1990, Arcana, Kraków 2005.

Galij-Skarbińska S., Model zmiany cywilnych stużb specjalnych w Polsce w latach 1989-1990, Wydawnictuo Adam Marszałek, Toruń 2019.

Kowal P., Koniec systemu władzy. Polityka ekipy gen. Wojciecha Jaruzelskiego w latach 1986-1989, Trio, Warszawa 2012.

Kozłouski T., Koniec imperium MSW. Transformacja organów bezpieczeństwa państwa 1989-1990, Instytut Pamięci Narodowej, Warszawa 2019.

Kufel J., Kampania wyborcza kandydatów KO Solidarność na łamach „Gazety Wyborczej” przed wyborami czerwca 1989 r. w Polsce [w:] Dwa dwudziestolecia. Geopolityka, państwo, społeczeństwo, red. P. Hauser, W. Mazurczak, Wydawnictuo Poznańskie, Poznań 2010.

Okragły Stót. Dokumenty i materiały, red. W. Borodziej, A. Garlicki, Zapol, Szczecin 2004.

Okragty Stót. Dwadzieścia lat później, red. W. Polak (i in.), Wydawnictuo Adam Marszałek, Toruń 2009.

Skórzyński J., Rewolucja Okrąłego Stołu, Społeczny Instytut Wydawniczy Znak, Kraków 2009.

Trembicka K., Okrągty stót w Polsce: studium o porozumieniu politycznym, Wydawnictuo Uniwersytetu Marii Curie-Skłodouskiej, Lublin 2003.

Prasa

Bojko L., Chłopi czekali cała zimę, „Gazeta Wyborcza”, 30.06.1989.

Bratkouski S., Bez nerwów, „Gazeta Wyborcza”, 13.06.1989.

Czym jest, czym ma być NSZZ Solidarność, „Tygodnik Solidarność”, 9.06.1989, nr 2(39).

Dworak J., Obliczalność, „Tygodnik Solidarność”, 25.08.1989, nr 13(50).

Giełżyński W., „Tuancie” to po chińsku - solidarność, „Gazeta Wyborcza”, 10-12.06.1989.

Gzyło A., Słowiński W., Rządowy projekt urynkowienia. Jakie ceny?, „Gazeta Wyborcza”, 30.06.1989.

Krall H., Maty skrawek ziemi, „Gazeta Wyborcza”, 8.06.1989.

Leski K., Kropka nad i, „Gazeta Wyborcza”, 20.06.1989.

Mazowiecki T., Spiesz się powoli, „Tygodnik Solidarność”, 14.07.1989, nr 7(44).

Michnik A., Kiedy porozmawiamy o wielkiej koalicji, „Gazeta Wyborcza, 13.06.1989.

Michnik A., Polska - ZSRR. Patka i kompleks, „Gazeta Wyborcza”, 9.06.1989.

Michnik A., Wasz Prezydent. Nasz Premier, „Gazeta Wyborcza”, 4.07.1989.

Michnik A., Pożegnanie doktryny Breżniewa, „Gazeta Wyborcza”, 5.07.1989. 
Michnik A., Radość... i chwila namystu, „Gazeta Wyborcza”, 6.06.1989.

Michnik A., Wasz Prezydent. Nasz Premier, „Gazeta Wyborcza”, 4.07.1989.

Michnik A., Z kim usiadziemy, „Gazeta Wyborcza”, 16.06.1989.

Najpierw reformy, potem rzad. Z Bronisławem Geremkiem rozmawia Eugeniusz Smolar z polskiej sekcji BBC, „Gazeta Wyborcza”, 23.06.1989.

Naszkouska K., Mięso: za ile?, „Gazeta Wyborcza”, 28.06.1989.

Nikt $w$ historii jeszcze tego nie przerabiat. Z Jackiem Kuroniem rozmawia Jacek Żakowski, „Gazeta Wyborcza”, 15.06.1989.

Obniżka poziomu życia. Oświadczenie Prezydium „Solidarności” w sprawie podwyżek cen, „Gazeta Wyborcza”, 28.06.1989.

Plan Marshalla dla Polski. Wypowiedź profesora Witolda Trzeciakowskiego, eksperta „Solidarności” ds. gospodarki, „Gazeta Wyborcza”, 24-26.06.1989.

Redakcja, Nasz szef - naszym premierem, „Tygodnik Solidarność”, 25.08.1989, nr 13(50).

Warszauski D., Poznać i dać się poznać, „Gazeta Wyborcza”, 8.06.1989.

Wieczorek W., Krajobraz po wyborach, 16.06.1989, nr 3(40). 